\title{
UTILITY SERVICE TO COOPERATIVES
}

\section{ISRAEL PACKEL $\dagger$}

The judiciary and the legal profession have recently been subjected to severe attack on the ground that they have failed to keep pace with social and economic developments. The unfortunate labelling of the judicial process either as a matter of predilection or as a matter of fixed principle makes it incumbent upon the bench and bar to exercise extreme care in coping with new problems of great social, economic or political import. The recognition of new facts and the exercise of a sound judgment as to the significance to be attached to those facts should always be important features of the judicial process. "Ex facto ius oritur. That ancient rule must prevail in order that we may have a system of living law." 1

Great public interest is currently centered about the social, economic and political significance of the cooperative movement. ${ }^{2}$ The recent tremendous growth in the number of cooperatives engaged in rural electrification presents a few of the many legal questions resulting from the movement. A particularly interesting question arises out of the demand by such cooperatives for service from public utilities in order to serve the members or stockholders of the cooperatives.

More than two hundred and fifty cooperatives formed in the United States during the past two years for the purpose of rural electrification have applied to the utilities for the purchase of electricity. Some utilities have offered contracts to furnish service which usually provide for a duration of a limited number of years. Others have demanded excessive rates or have insisted upon the imposition of objectionable conditions which were not related to the sale of electricity. In each case, therefore, the ultimate question presented is whether utilities are under a legal duty to serve cooperatives which have been formed to obtain service for utilization by their members or stockholders. This question involves a series of fundamental problems of public utility law. What constitutes a dedication to furmish a particular kind of service? Need there be a special dedication for wholesaling as contrasted to retailing? Is there any duty to serve competitors? What constitutes competition with a public utility? May a utility restrict its wholesale service only to public utilities and discriminate against cooperatives which are not public utilities within the meaning of public utility legislation?

†A. B., I929, LL. B., I932, LL. M., I933, University of Pennsylvania; member of the Philadelphia Bar; contributor to legal periodicals.

I. Brandeis, J., dissenting in Adams v. Tanner, 244 U. S. 590, 600 (I9I6).

2. See The Meaning of Cooperative Enterprise to America, Part II of REPORT of THE INQUIRY ON COOPERATIVE ENTERPRISE IN EUROPE (I937) 8r-I3I. 
Although fundamental questions of public utility law are involved, it is important, as has been pointed out, that there be an appreciation of the facts pertaining to the social, economic and political implications of the cooperative movement. $^{3}$ It may well be that upon a proper analysis those facts will not be of such a character as to affect the solution of any of the indicated problems. At the least, however, a recognition of the existence of those facts is important in order to avoid the possibility of merely following precedent blindly and without reason.

The cooperatives which have demanded service from public utilities are not essentially different from other types of cooperatives which for many years have been engaged in diverse fields of activity. A great deal of variety exists in the organization and in the mode of operation of cooperatives. This is to be expected in view of the wide scope of the activities of the many types of cooperatives such as consumers' cooperatives, marketing cooperatives, trade associations, unions, and the various ramifications of financial cooperatives. ${ }^{4}$ Cooperatives are primarily an economic device-a modus operandi comparable to other means of accomplishing economic cooperation such as the partnership, the principal-agent relationship or the ordinary corporation. Cooperatives may be unincorporated. The desire to avoid unlimited liability, however, has usually led to their incorporation. They may be incorporated under the laws of the state which are applicable to business corporations or under those which are applicable specifically to cooperatives. In some instances the lack of a satisfactory incorporation act has led to their incorporation under the laws of a foreign state. Their organization may be on a stock basis or on a non-stock or membership basis. ${ }^{5}$ In any event, the main underlying principles appear to be (I) non-profit service with a limited return or no return on capital investment, and (2) substantial equality in ownership and control among the persons to be served. ${ }^{6}$

3. "The economist has been too little aware of the legal requirements and the lawyer too little versed in the fundamentals of economics and business for either to get an adequate grasp of the issues involved in the organization and operation of cooperatives." NourSE, THE Legal Status of Agricultural Co-operation (I928) viii.

4. A general idea of the wide scope of these activities can be gleaned from the following reports published in the past few years through the Cooperative Division of the Farm Credit Administration: in 1935, KNaPP AND LISTER, CoOperative PURCHAsING of FarM SUPplies; in I936, Elsworth, Statistics of Farmers' Cooperative Business Organizations, 1920i935; Fetrow, Cooperative Marketing of Agricultural Products; Gardner, Cooperation in Agriculture, a Selected and Annotated Bibliography; Hulbert, Organization

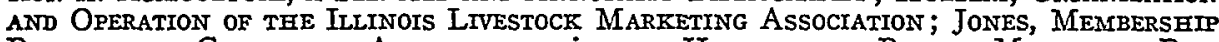
Relations of Cooperative Assoctations ; in 1937, Hensley and Borden, Marketing PoLictes of the Caltfornia Walnut Growers Association; Stitts and Laughlin, Organization and Operating Problemss of Nebraska Cooperative Creanieries.

5. An elaboration of these differences and a detailed discussion of the statutes specifically providing for the incorporation of marketing cooperatives appear in the dissenting opinion of Mr. Justice Brandeis in Frost v. Corporation Comm. of Okla., 278 U. S. 5I5, 537-546 (I929).

6. In Evans \& Stokdyk, The Law of Agricultural Cooperative Marketing (I937) 3, 4, the basic principles are said to be: (I) "limitation upon the voting power and restrictions upon alienation of voting stock or membership interests"; (2) "limiting the use of proxies"; (3) "limitation of earnings upon invested capital"; and (4) "distribution of earnings or savings upon a patronage basis". 
The non-profit and democratic aspect of the cooperative movement has manifest political and social implications. Many people envisage a new social order in which cooperatives will supplant large corporate enterprises with their attendant evils flowing from the separation of ownership and control. ${ }^{7}$ The example of cooperation in foreign countries has been offered to show the value of the movement in the awakening of the public to its rights and obligations under democratic government. ${ }^{8}$ Whatever may be the implications of the cooperative movement, its success in bringing electricity to the rural areas of this country must be taken as an accepted fact. The Rural Electrification Administration, ${ }^{9}$ as of November I, 1937, has made contracts with approximately two hundred and eighty-eight cooperatives throughout the entire country for the loan of $\$ 54,478,968$ to finance the construction of 5I,4I8.9 miles of electric lines to serve approximately 182,545 customers. ${ }^{10}$

With this background, it may be appropriate to examine the typical situation in which a cooperative demands service from a power company. A group of farmers desire electricity. With the aid of county agents and farm leaders, a survey of the unserved farms and other premises is made. An application is made to the Government for a loan on the basis of the surveys and other information. Approval of the application is followed up by formal incorporation and thereafter by a loan contract pursuant to which money is made available for the construction of lines. A mortgage on the proposed system of the cooperative constitutes the security for the loan. The lines will be used to transmit electricity from a source of power to the premises of the consumers, and will be constructed for the cooperative by a contractor. Their location will to a certain degree depend upon the source of electricity, and this calls for the making of a wholesale energy contract.

Under such an energy contract the cooperative is billed for all the energy which passes through the meter at the point of connection between the lines of the utility company and those of the cooperative. The energy is trans-

7. "But Americans seeking escape from corporate domination have open to them under the Constitution another form of social and economic control-one more in keeping with our traditions and aspirations. They may prefer the way of cooperation, which leads directly to the freedom and the equality of opportunity which the Fourteenth Amendment aims to secure. That way is clearly open. For the fundamental difference between capitalistic enterprise and the cooperative-between economic absolutism and industrial democracy-is one which has been commonly accepted by legislatures and the courts as justifying discrimination in both regulation and taxation." Brandeis, J., dissenting in Liggett Co. v. Lee, 288 U. S. 5I7, 579 (I932).

8. In REPORT of the INQUiRY on CoOperative ENTERPRISE IN Europe, supra note 2, at 72 , it is said: "Cooperatives aid government, in the opinion of the majority of people interviewed, by creating a sense of responsibility and ownership among the members and by broadening their economic outlook, all of which makes for better citizenship. . . ."

9. The Rural Electrification Administration was originally set up pursuant to an executive order under the Emergency Relief Appropriation Act of I935, 49 STAT. II5 (I935), I5 U. S. C. A. $\$ 728$ n. (Supp. 1937). It is now an independent agency engaged in a ten year program under the Rural Electrification Act of 1936,49 STAT. 1363,7 U. S. C. A. \$\$ 9oI-9I4 (Supp. I937).

I0. The statistical data has been obtained from the Rural Electrification Administration by a letter dated November 8, I937. 
mitted over the lines of the cooperative, from which it is metered to the members of the cooperative, who are billed therefor by the cooperative. The revenues received by the cooperative from members are used to pay for electricity, for equal monthly interest and principal payments on the loan from the Government, for the salary of a manager, for maintenance and for other small overhead items. Any balance is available for reserves and for patronage refunds. With this factual explanation it will be easier to approach the question of the duty of utilities to furnish service to such cooperatives.

\section{Duty of Utilities to Furnish Ordinary Service}

The determination of whether a duty exists to give a particular type of service requires a preliminary examination as to the existence of a duty to give some kind of service. The baker, the grocery man and the butcher are under no duty to furnish service. The law, through a historical and legislative process, has ascribed a positive duty to serve only to certain callings, such as those of inn-keepers, common carriers and public utilities. ${ }^{11}$

The duty of public utilities to serve the public has been hung upon the peg of an affectation with a public interest and a devotion to the public use which has been aptly described as a "fiction intended to beautify what is disagreeable to the sufferers." 12 To be confronted at the outset with a fiction makes it difficult to build up a logical analysis of the duty to serve. If, however, the fiction is treated as merely a shorthand description of certain factual situations which have come to be recognized as requiring the performance of public duties, difficulty can be avoided. The propriety of this factual analysis is seen in the line of cases which treat as a question of fact the utility status of a company which, in the course of another business, incidentally serves a portion of the public. ${ }^{13}$ The same analysis is appropriate to the determination of whether cooperatives are to be treated as public utilities within the meaning of public service commission statutes, which question has already been discussed by the writer elsewhere. ${ }^{14}$

Where a company is engaged in the furnishing of service to another entity which in turn furnishes the service to the actual consumers, there is presented at times the question of the utility status of the company. Manifestly, if the company is also engaged in the furnishing of service to the public for consumption, it is a public utility. The question only arises in the

II. Robinson, The Public Utility Concept in American Lawe (I928) 4I HARv. L. Rev. 277.

12. Holmes, J., dissenting in Tyson \& Bro. v. Banton, 273 U. S. 4I8, 446 (1927); cf. Hamilton, Affectation with a Public Interest (1930) 39 YALE L. J. I089; McAllister, Lord Hale and Business Affected with a Public Interest (I930) 43 HARv. L. REv. 759.

I3. State ex rel. Danciger \& Co. v. Public Serv. Comm., 275 Mo. 483, 205 S. W. 36 (Igr8); Wingrove v. Public Serv. Comm., 74 W. Va. I90, 8I S. E. 734 (IgI4); Cawker v. Meyer, I47 Wis. 320, 133 N. W. 157 (IgII); cf. Holdred Collieries v. Boone County Coal Corp., 97 W. Va. 109, 124 S. E. 493 (I924). 4II.

I4 Packel, Commission Jurisdiction over Utility Cooperatives (I937) 35 MICH. L. REv. 
situation where the company confines its activities to the furnishing of service to non-consumers such as distributing companies. Courts, ${ }^{15}$ in the absence of an express legislative declaration, ${ }^{16}$ have held that such service to a single purchaser does not make a company a public utility. This rule, however, has not prevented the courts from treating such a company as a public utility because of unusual contractual or ownership control which is exercised over the purchaser in the furnishing of service to the public. ${ }^{17}$ Where a company which does not serve consumers purports to serve any non-consumer company engaged in the resale of the service, it would appear that the company is a public utility under a duty to furnish such service to whomsoever demands it.

The determination that a particular utility company is under a duty to give service clears the way for the more difficult question as to the scope of the duty of the utility. In speaking of the scope of this duty, it is important to differentiate between the various kinds of utilities. The courts, in deciding cases involving one type of utility, have quite properly resorted to cases involving other types. ${ }^{18}$ To attempt to distinguish a case merely on the ground that it involves a railroad as contrasted to a telephone company is just as unsound as to attempt in a railroad case to follow a telephone case which turned upon facts peculiar to telephone companies. ${ }^{19}$

\section{Duty of Utilities to Make Physical Connections}

Cases involving the physical connection of utilities are good examples of the situation where the facts pertaining to the physical characteristics of a utility are significant. At the one extreme is the railroad which in making ordinary use of its facilities does not make any physical connection with other lines. At the other extreme is the electric utility which always connects with the system of the patron in order to give ordinary service. The telephone utility is in a peculiar position since a physical connection is always necessary, but it is made between its main system and its apparatus and lines which are installed in the premises of the consumer.

Not only are there these differences between the various types of utilities, but also there are the differences in the kinds of physical connections which are made by a particular type of utility. The history of railroad

I5. Colorado Utilities Corp. v. Public Utilities Comm., 99 Colo. I89, 6I P. (2d) 849 (1936) ; cf. Ford Hydro-Electric Co. v. Aurora, 206 Wis. 489, 240 N. W. 4I8 (1932). (1923).

I6. Southern Okla. Power Co. v. Corporation Comm. of Okla., 96 Okla. 53, 220 Pac. 370

17. Railroad Comm. of Tex. v. Humble Oil \& Refining Co., ror S. W. (2d) 6I4 (Tex. Civ. App. I937).

I8. "Gas cases must be metamorphosed, for super-power control did not spring 'full grown' but is an eclectic of court experience in several lines of cases." Rose, Control of SuperPower (193I) 80 U. OF PA. L. REv. 153, I54; cf. Wyman, The Obligations of Public Service Companies to Make Connections (I909) 22 HaRv. L. Rev. 564.

I9. See Dickinson, Legal Rules: Their Function in the Process of Decision (I93I) 79 U. of PA. L. REv. 833, 860 . 
regulation for example shows an interesting enlargement of federal administrative control based upon different kinds of physical connections. ${ }^{20}$ Originally, under the 1887 act, ${ }^{21}$ the only statutory provision was that facilities should be afforded for the interexchange of traffic. This was extended in I9Io ${ }^{22}$ to impose the duty of making switch connections to lateral branch roads. In IgI2 the legislation was extended ${ }^{23}$ to empower the Interstate Commerce Commission to establish physical connections between railroad lines and the docks of water carriers. Then in 1920 the Transportation Act empowered the Commission to order connections between interstate carriers. ${ }^{24}$ Variety is also seen in telephone connections. The ordinary connection to furnish telephone service is to be contrasted to the physical connection between two telephone companies, which requires a switchboard connection. Such a switchboard connection is manifestly more than an ordinary single connection, since it requires the maintenance of facilities to enable all the patrons on the one line to connect with all the patrons of the other line. Then again, there is joint use of physical facilities, as in the situation where the wires of two companies are maintained on the same poles.

In electric utilities there likewise might be a joint use of physical facilities, but otherwise there appears to be no variety in the type of physical connection. It should be noted, however, that there is the type of dual connection contemplated by the Federal Water Power Act as amended in 1935, which empowers the Federal Power Commission to order the exchange of energy between companies. ${ }^{25}$ Under such a provision energy could be generated at a dam, delivered to the lines of a nearby company by a connection, and utilized by another connection made hundreds of miles away. ${ }^{26}$

The difference in these kinds of connections has not escaped judicial cognizance. Thus the denial of the duty to make a physical connection at the end of a railroad line, which connection was sought solely to obtain use of terminal facilities, ${ }^{27}$ was held to be consistent with the imposition of the duty to make a connection for the purpose of receiving cars and hatuling them in commerce. ${ }^{28}$ An entirely different situation is presented in the transportation cases when a physical connection of tracks is sought by a company, (1926).

20. The development is traced in Alabama \& V. Ry. v. Jackson E. Ry., 27I U. S. 244

2I. 24 Stat. 379 (I887), 49 U. S. C. A. § I (9) (I929).

22. 36 STAT. 547 (IgI0), 49 U. S. C. A. \$ I (9) (I929). (1929).

23. 37 Stat. 568 (IgI2), as anended, 4I Stat. 483 (I920), 49 U. S. C. A. §6 (I3)

24. 4 I Stat. 475 (I920), 49 U. S. C. A. § I (9) (I929).

25. 49 Stat. 848 (I935), I6 U. S. C. A. $\$ 824 a$ (b) (Supp. I937).

26. A voluntary arrangement of this character was a part of the contract between $T$. V. A. and the Alabama Power Company which was upheld in Ashwander v. Tennessee Valley Auth., 297 U. S. 288 (1935).

27. Grand Trunk R. R. v. Michigan R. R. Comm., 23I U. S. 457 (1913).

28. Pennsylvania Co. v. United States, 236 U. S. 35 I (I9I5). 
not merely to deliver cars, but to enable the company to continue the hauling of cars thereon. ${ }^{29}$

A similar judicial recognition of the difference in types of physical connections is seen in the telephone cases. A physical connection of the lines of two companies has been recognized as being different from the joint use of facilities. ${ }^{30}$ Then again, the connection which a farmer desires in his home is different from the connection which he would want if he built his own line twenty miles to the telephone switchboard. ${ }^{31}$ Likewise, the service which one telephone company would demand of another in making a switchboard connection would be different from the service granted to the ordinary patron. $^{32}$ For this reason it has been held that there is no duty to make a switchboard telephone connection for another company in the absence of a statute expressly imposing that duty. ${ }^{33}$

The ownership or control of the line and the apparatus in the premises of the patron, which exists in the telephone cases, is to be contrasted with the situation in regard to the electric utilities. In the telephone cases the utilities and the authorities have supported the position that such control must be exercised because of the effect upon the telephone system as a whole. ${ }^{34}$ The electric utilities, however, have refrained from insisting upon having the right of control or ownership over the wiring or over the apparatus in the premises of their patrons. For the electric utility, therefore, the physical connection of its facilities with those of the patron always exists. Thus the denial of service to a cooperative is certainly not to be based upon the fact that a physical connection takes place. The physical characteristics surrounding the furnishing of service to a cooperative which distributes the energy to its members, are no different from the characteristics which would surround the furnishing of service to a cooperative which consumes the energy for the purpose of processing the products of its members. ${ }^{35}$

29. A statutory provision for such a connection was held unconstitutional in Philadelphia, M. \& S. St. Ry.'s Petition, 203 Pa. 354, 534 Atl. I9I (1902). But cf. Lincoln Traction Co. v. Omaha L. \& B. Ry., 108 Neb. I54, 187 N. W. 790 (1922).

3o. Wisconsin Telephone Co. v. Railroad Comm. of Wis., I62 Wis. 383,156 N. W. 614 (Igr6) ; cf. Owl Protective Co. v. Public Serv. Comm. of Pa., I23 Pa. Super. 382, I87 Atl. 229 (1936). (I9II).

3I. Home Telephone Co. v. Sarcoxie Light \& Telephone Co., 236 Mo. II4, I39 S. W. 108

32. Such a connection has been referred to as one between companies rather than a mere physical connection of lines. Pioneer Tel. \& Tel. Co. v. State, 77 Okla. 216, 186 Pac. 934 (I920).

33. Home Telephone Co. v. Sarcoxie Light \& Telephone Co., 236 Mo. II4, I39 S. W. 108 (IgII) ; and see cases cited infra note 62.

34. New England Tel. \& Tel. Co. v. Department of Pub. Util., 262 Mass. 137, 159 N. E. 743 (1928).

35. Cf. Wisconsin Rural Electrif. Coordination Comm. v. Wisconsin-Mich. Power Co., I7 P. U. R. (N. S.) 39 (Wis. Pub. Serv. Comm. I936). 


\section{Duty of Utilities to Make Extensions}

Utilities may pick the general area which they desire to serve. They may not, however, pick or choose which parts of that area they will serve and which parts they will not serve. As pointed out by the Supreme Court of the United States in People ex rel. N. Y. \& Queens Gas Co. v. McCall, ${ }^{36}$ one of the duties of an administrative commission is to correct "this disposition to serve where it is profitable, and to neglect where it is not. . . ." 37 The determination whether a particular place is within the territory which a utility purportedly serves presents many difficulties. ${ }^{38} \mathrm{Mr}$. Justice Cardozo has suggested that the test based upon the scope of the undertaking assumed by the utility is not only illusory but is also inappropriate. ${ }^{39} \mathrm{He}$ states that the indefiniteness of the test makes it illusory. Its inappropriateness, he points out, arises from the misconception that the duty of utilities is based upon a supposed contract or compact with the state, whereas in fact the duty arises as a matter of law because of the public interest involved.

Prior to formal incorporation, the members of the electric cooperatives which have demanded service from the utilities have almost invariably asked those utilities to make extensions to serve the inhabitants of the territory. After organization, however, the plan of the cooperatives is to meet the unfulfilled demand of the farmers by building the lines of the cooperative to the existing lines of the utilities, so that an extension by the utility is unnecessary. The demand for an extension of lines to a new area is entirely different from the demand for an ordinary connection in order to furnish service which will be consumed in a different place.

It has been contended that the significant factor in such a situation is not the point of supply, which is admittedly within the area served by the utility, but rather the point of consumption. ${ }^{40}$ An analogous contention has been adequately disposed of by the Supreme Court of the United States in a taxation case with regard to the character of the generation and the ensuing distribution of electricity among the states. ${ }^{41}$ It has also been met in cases involving the furnishing of service by a utility company ${ }^{42}$ or by a munici-

36. 245 U. S. 345 (19I7).

37. Id. at 35 I.

38. Interstate Commerce Comm. v. Oregon-Wash. R. R. \& Nav. Co., 288 U. S. 14 (1933).

39. Id. at 47 (dissenting opinion).

40. The result in Oklahoma Natural Gas Co. v. Corporation Comm. of Okla., 88 Okla. 5I, 2II Pac. 40I (I922), seems to indicate that the contention met with success in that case.

4I. Utah Power \& Light Co. v. Pfost, 286 U. S. I65 (I932).

42. "If Suburban Company may lawfully sell electrical current to Bucks County Company in Doylestown Township or Doylestown Borough, it is none of appellants' concern what the latter may do with it after it is delivered there. . . " Kulp v. Public Serv. Comm., 82 $\mathrm{Pa}$. Super. 83, 88 (1923) ; cf. Citizens Elec. Illuminating Co. v. Lackawanna \& W. V. Power Co., $255 \mathrm{~Pa}$. 145, $99 \mathrm{Atl}$. 462 (1916), where the point of delivery was outside the territorial limits of the vendor. But $c f$. Holston River Elec. Co. v. Hydro-Electric Corp., 17 Tenn. App. $122,66 \mathrm{~S}$. W. (2d) 217 (1933). 
pality ${ }^{43}$ within its territorial limits, even though consumption will take place outside those limits. Likewise, it has been held that the territorial agreement of a utility not to serve an area is not violated by serving a cooperative outside that area which in turn would serve persons in the area. ${ }^{44}$ The reasoning in these cases is simply to the effect that from a practical standpoint the utility is engaged in generating and transporting a product. The generation and the transportation, or transmission, are separate activities. ${ }^{45}$ The utility, when it transmits the energy to a given point and delivers it to a patron, has completed its function. It is immaterial to the utility, therefore, how or where the patron is using the electricity so long as the patron is not making an unlaw ful use of the energy.

\section{Duty to Furnish Wholesale Service}

The word "wholesale" is used herein in the sense of furnishing service to a separate independent agency such as another company or a cooperative which in turn will furnish the service to others for consumption. This definition conforms generally with that given in the amended Federal Water Power Act. ${ }^{46}$ In passing, it might be noted that the word is at times used also to refer to large scale activities. Thus it has been said that railroads, as contrasted to other utilities, have not been permitted, except in certain cases such as carload service, to pass on to the large sized patrons the economies resulting from large scale service. ${ }^{47}$ Also in passing, there should be distinguished the situation referred to as "meter pooling", under which utilities furnish service to two or more premises and an attempt is made to obtain the benefit of a sliding scale of rates by adding the amount of consumption shown on the two or more meters. ${ }^{48}$

Attempts have been made to avoid the duty of furnishing wholesale service on the ground that the duty to serve extends only to the ultimate patron or consumer. The contention was very effectively answered by the Supreme Court of the United States in Interstate Commerce Comm. v. Dela-

43. Dyer v. Newport, I23 Ky. 203, 94 S. W. 25 (I906); see The Maggie P., 25 Fed. 202 (C. C. E. D. Mo. I885) ; Miller v. Orrville, 48 Ohio App. 87, 192 N. E. 474 (I934). But cf. Western N. Y. Water Co. v. Buffalo, I24 Misc. 257, 208 N. Y. Supp. 387 (Sup. Ct. I925), aff'd, 2I3 App. Div. 458, 210 N. Y. Supp. 6II (4th Dep't, 1925), rev'd, 242 N. Y. 202, I5I N. E. 207 (1926).

44. Wisconsin Rural Electrif. Coordination Comm. v. Northern States Power Co., I7 P. U. R. (N. S.) I24 (Wis. Pub. Serv. Comm. I936).

45. "Notwithstanding the special characteristics of electric energy, the company is engaged in producing and selling an article of trade." Hughes, C. J., in Broad River Power Co. v. Query, 288 U. S. I78, I8I (1933).

46. "The term 'sale of electric energy at wholesale' when used in this Part means a sale of electric energy to any person for resale." 49 STAT. 847 (I935), I6 U. S. C. A. \$ 824 (d) (Supp. 1937).

47. Robinson, Business Enterprise and the Public Utility's Duty to Serve Without Discrimination (I928) I3 MrNN. L. Rev, 104, I09.

48. Cf. United States v. American Water-Works Co., 37 Fed. 747 (C. C. D. Neb. 1889); Hunter v. Public Serv. Comm., I Io Pa. Super. 589, I68 At1. 54I (I933). 
ware $L . \mathcal{E} W . R . R .49$ It was there pointed out that "nothing in the duties of a common carrier by the remotest implication can be held to imply the power to sit in judgment on the title of the prospective shipper who has tendered goods for transportation." 50 By the same token, it would seem that a utility cannot sit in judgment on the direct or indirect use of its product which will be made by a prospective patron. The duties imposed by ordinary statutes, as pointed out by the Supreme Court in the case just cited and as pointed out with reference to an electric utility, ${ }^{51}$ are for the benefit of the public and are not to be limited by any construction that the statutes refer only to the consuming public.

A group of cases ${ }^{52}$ do state, however, that in the absence of an express statutory provision, ${ }^{53}$ a utility is under a duty to furnish wholesale service only when it has purported generally to furnish it. The rule was given lip service in the case of North Carolina Pub. Serv. Co. v. Southern Power \& Light Co. ${ }^{54}$ in which it was held that the company was engaged in the business of wholesaling because it sold to its subsidiary and to the plaintiff which was attempting to enjoin the cutting off of service. ${ }^{55}$ Even less than lip service was given to the rule in Holmes Elec. Co. v. Carolina Power \& Light Co., ${ }^{56}$ where it was held that there was no duty to furnish wholesale electric service because of the conclusion by the lower court that the defendant was not engaged in selling at wholesale. The appellate court ignored, however, the finding of the lower court that the company had "sold its current to municipal corporations for redistribution among the citizens of the municipality and community and to large manufacturing corporations who purchase electric current in large quantities for industrial purposes and for redistribution to its employees." 57

Statements that the duty to furnish wholesale service cannot be imposed in the absence of a dedication to furnish such service appear in various types of cases involving competition between the utility and the prospective patron.

49. 220 U. S. 235 (I9II).

50. Id. at 252 .

51. North Carolina Pub. Serv. Co. v. Southern Power Co., 282 Fed. 837 (C. C. A. $4^{\text {th, }}$ I922), cert. denied, 263 U. S. 508 (Ig24).

52. Chicago Dist. Pipe Line Co. v. Illinois Commerce Comm., 36r Ill. 296, I97 N. E. 873 (1935); Southwestern Natural Gas Co. v. Cherokee Pub. Serv. Co., I72 Okla. 325, 44 P. (2d) 945 (1935).

53. In a few states there are express statutory provisions for the sale of electricity at wholesale. Mass. Gen. Laws (I932) c. I64, \$92A; Neb. Comp. Stat. (I929) § 70-50I; N. H. Laws I929, c. I79; cf. S. C. Acts 1935 , no. 65 , § I7. In Virginia a statute provides that there is no duty to serve others engaged in a similar business. VA. CODE (I936) $\$ 4066$ [but cf. $\$ 4057(24)]$.

54. 282 Fed. 837 (C. C. A. 4th, 1922), cert. denied, 263 U. S. 508 (1924) ; cf. North Carolina Pub. Serv. Co. v. Southern Power Co., I79 N. C. I8, ror S. E. 593 (Igrg).

55. But cf. People ex rel. N. Y. Edison Co. v. Public Serv. Comm., rgI App. Div. 237, I8I N. Y. Supp. 259 (Ist Dep't, I920).

56. 197 N. C. 766 , I50 S. E. 62 (1929).

57. Id. at 768, I 50 . S. E. at 622. 
This is seen in cases which will be discussed below, ${ }^{58}$ in which submetering or breakdown service is demanded from a utility by a patron which will resell to persons who would otherwise be customers of the utility. In the absence of this competitive aspect of the situation, it would appear that the utility is under a duty to furnish service irrespective of whether the purchaser will consume or will resell the service. The use to which the service is to be put may be significant for promotional or for other reasons relating to rates, ${ }^{59}$ but the use should not be a factor in determining whether a duty to furnish the service exists. It might well be that in unusual cases the load demanded by a cooperative would be such as to require an unusually large additional investment by the utility. In such cases the investment will or will not be warranted by the surrounding facts which essentially bear no relationship to the question whether the purchaser is a cooperative or a large industrial consumer. ${ }^{60}$

\section{Effect of the Voluntary Furnishing of an Unusual Service}

In many cases utilities have voluntarily engaged in furnishing a type of service which they had not been obligated to furnish. The absence of any ordinary duty on the part of a telephone company to make a switchboard connection for another telephone company has already been discussed. ${ }^{61}$ The problem of the effect of a telephone company's voluntarily making such a connection has arisen in a good number of instances. Many of the cases have held that such conduct creates no legal duty to third persons or to the contracting party other than that set forth in the contract. ${ }^{62}$ Some courts have held, however, that the making of a connection does impose a duty to continue the connection even though the duty under the terms of the contract may have terminated. ${ }^{63}$ There is also some authority to the effect that the

58. See infra notes $8 \mathrm{i}-85$.

59. Public service commissions have held that the functional use of the service furnished to cooperatives and other factors were sufficient to justify a separate rate classification. Wisconsin Rural Electrif. Coordination Comm. v. Lake Superior Dist. Power Co., I6 P. U. R. (N. s.) 238 (Wis. Pub. Serv. Comm. 1936) ; In the Matter of the Investigation of Reasonable Wholesale Rates for Electric Power to be Furnished Rural Electric Cooperative Associations, Admin. Order No. 22 (Ky. Pub. Serv. Comm., May I5, 1937). Rural Electrif. Admin. Release, Nov. 5, I937, at 2, quotes Administrator John M. Carmody as follows: "To mention only a few States, operating companies have filed special wholesale rates to rural cooperatives in New Jersey, Pennsylvania, Virginia, South Carolina, Indiana, Illinois, Kentucky, Arkansas, Missouri, Wisconsin, Minnesota, Lowa, Oklahoma, Kansas, Texas, Colorado, Montana, Washington and Oregon."

6o. Cf. Wisconsin Rural Electrif. Coordination Comm. v. Wisconsin-Mich. Power Co., I7 P. U. R. (N. s.) 39 (Wis. Pub. Serv. Comm. I936).

6I. See supra note 33.

62. Oklahoma-Ark. Telephone Co. v. Southwestern Bell Telephone Co., 45 F. (2d) 995 (C. C. A. 8th, I930), cert. denied, 283 U. S. 822 (I93I) ; State v. Northwestern Bell Telephone Co., 214 Iowa 100, 240 N. W. 252 (1932) ; Clay County Coop. Telephone Ass'n v. Southwestern Bell Telephone Co., I07 Kan. 169, 190 Pac. 747 (1920); cf. Atchison T. \& S. F. Ry. v. Tiedt, 196 Fed. 348 (C. C. A. 7th, 19I2).

63. State ex rel. Goodwine v. Cadwallader, I72 Ind. 619, 87 N. E. 644 (Ig09); ClintonDunn Telephone Co. v. Carolina Tel. \& Tel. Co., I59 N. C. 9, 74 S. E. 636 (I9I2). 
making of such a connection by a utility constitutes a waiver of the independence which could otherwise be asserted and that therefore the utility is obligated to furnish the unusual service to whomsoever demands it. ${ }^{64}$

The foregoing line of cases is not particularly significant to the problem with regard to rural electric cooperatives. A court may attempt, however, to follow those cases blindly without taking cognizance of the fact heretofore noted that the telephone switchboard connection differs from ordinary telephone service and that, therefore, this duty to connect does not exist under ordinary circumstances. It might be mentioned, however, that the varying conclusions in the telephone cases, on proper analysis, might be reconciled on the basis of whether the company, in view of all the circumstances, has become a public utility not only in furnishing ordinary service but also in giving the unusual service which is of the same general character. It is true that a utility engaged in merchandising appliances may be under no legal duty to merchandise, ${ }^{65}$ and similarly a railroad may contract for hacking ${ }^{60}$ or for express service ${ }^{67}$ with one company and not with another. But in such cases the extraordinary service is merely incidental to the regular service and is not of the same general character as that which the company customarily furnishes. Under this suggested analysis each case would present a question of fact whether, under the particular circumstances, the utility, in furnishing the unusual service, comes within the concept conveniently referred to as a devotion to the public use. ${ }^{68}$ Thus a company which has made merely one telephone switchboard connection might be considered as having devoted its property to such a service because the company held itself out to furnish it, although only one customer presented itself. ${ }^{69}$

The voluntary furnishing of electric service has not been the subject of much judicial consideration. The courts have not spoken of such conduct as constituting a waiver of independence, but have rather based their decisions on the ground that there has been a devotion to the public use. ${ }^{70}$ It might be mentioned that service cannot be demanded as a matter of right at lower rates than those set forth in the wholesale contract unless the contract is abrogated by a commission. ${ }^{71}$ It has also been held that a dispute as to the

64. State ex rel. Pub. Serv. Comm. v. Skagit River Tel. \& Tel. Co., 85 Wash. 29, I47 Pac. 885 (1915).

65. Cf. Consumers' Sanitary Coffee \& Butter Stores v. Illinois Commerce Comm., 348 III. 6r5, I8I N. E. 4II (I932).

66. Donovan v. Pennsylvania Co., I99 U. S. 279 (1905).

67. Express Cases, II7 U. S. I (I885).

68. See Owl Protective Co. v. Public Serv. Comm. of Pa., I23 Pa. Super. 382, I87 At1. 229 (1936).

69. "But whether or not the use is for the public does not necessarily depend upon the number of consumers; for there may be only one, and yet the use be for the public. . . ." Cawker v. Meyer, I47 Wis. 320, 325, I33 N. W. I57, I59 (IgII).

70. See cases cited supra notes $52,54,55$.

7I. Suburban Power Co. v. Public Util. Comm., I23 Ohio St. 275, I75 N. E. 202 (I93I). 
interpretation of a wholesale contract is manifestly no justification for an attempt to terminate service under that contract. ${ }^{\mathbf{2}}$

\section{Utility Service to Rivals}

In the ordinary course of business, competition calls for rivalry and not cooperation. To demand service from a competitor, however, is not unknown in the public utility field. The imposition of a duty to furnish such service nonetheless has led one judge to say that a "more dangerous blow could not well be struck at vested interests." 73 The facilities of a utility must often be resorted to by rival utilities in carrying on their activities. The construction of a railroad may require the hauling of materials or rolling stock on the line of a rival. A telegraph company may require the use of the service of another company to reach isolated parts of the country. The electric cooperative demands service for supplying its own premises as well as for supplying the premises of its members or stockholders.

A preliminary question to be determined is whether the cooperatives recently formed throughout the country for the purpose of rural electrification are to be deemed rivals of the utilities from which they purchase or desire to purchase electricity. It has been pointed out that these cooperatives have been organized to serve persons who have not been receiving service. It follows, therefore, that no existing customers will be taken away from the utilities. It hardly could be claimed that a cooperative is competing in such a case, especially when it purchases from the utility all the electricity which it uses. $^{74}$ It has been contended, however, that the effect of the action of the cooperatives in serving such areas is to take away potential customers of the utilities. $^{75}$ The question has been discussed in a recent decision of the Wisconsin Public Service Commission. In the following language, that Commission pointed out that it did not lie in the mouth of the utilities to take a dog in the manger attitude:

"So far as furnishing service to a cooperative serving in the same service area as the vendor utility is concerned, we do not believe that the utility's failure to completely service the area can be invoked as an impediment against furnishing service to another agency which has been successful in selling its service in the area." 76

72. Consolidated Gas. Elec. Light \& Power Co. v. United Rys. \& Elec. Co., 76 F. (2d) 535 (C. C. A. 4th, 1935).

73. Waddill, J., dissenting in North Carolina Pub. Serv. Co. v. Southern Power Co., 282 Fed. 837, 849 (C. C. A. 4th, I922), cert. denied, 263 U. S. 508 (I924).

74. See People ex rel. N. Y. Edison Co. v. Public Serv. Comm., Igr App. Div. 237, I8r N. Y. Supp. 259 (Ist Dep't, I920).

75. In Simpkins v. Corporation Comm. of Okla., 67 P. (2d) 96r (Okla. I937), the court held that a new company could enter a territory in which an old company was giving service to a few, notwithstanding the conclusion of the Commission that the old company should render the service if and when the growth of the community required it.

76. Wisconsin Rural Electrif. Coordination Comm. v. Wisconsin Pub. Serv. Corp., I3 Wis. Pub. Serv. Comm. Rep. I32, r38 (1936). Accord: Wisconsin Rural Electrif. Coordination Comm. v. Wisconsin Gas \& Elec. Co., I7 P. U. R. (N. s.) 3 I (Wis. Pub. Serv. Comm. 1936). 
A similar argument was presented to the Supreme Court of the United States in a railroad connection case where the railroad contended that the furnishing of new facilities would cause shipments to be made over a road of another company instead of over its own road. ${ }^{77}$ The Court pointed out, however, that the lack of new facilities did not mean that the road of the company would be used, but rather tended "to diminish, if not to extinguish the trade." 78 The Court further stated: "In truth, however, competition in the case of either cattle or wood lies more in assertion than in substantial fact." 79 Another Supreme Court decision ${ }^{80}$ presents a further aspect of the question in that it emphasizes the significance of an administrative determination as to the existence and.effect of competition. In that case it was held that the finding of fact by the Interstate Commerce Commission with regard to competition precluded the railroad from asserting any power to deny service to persons engaged in receiving small shipments and making them into carloads in order to gain the benefit of carload rates. Thus where a cooperative is engaged solely in serving the fringe of a territory served by a utility, a court would probably be influenced by an administrative finding of fact as to whether actual competition existed.

The significance of the administrative determination is particularly emphasized in the submetering cases. The landlord who attempts to purchase all the electricity needed for a building in order to meter the current to the tenants, has generally been unsuccessful in the courts. New Jersey ${ }^{81}$ and District of Columbia ${ }^{82}$ courts have upheld commission findings of fact that the practice of submetering was contrary to the public interest. In Florida, where there is no commission regulation of electric utilities, the regulation of a utility which prohibited submetering was upheld. ${ }^{83}$ In such cases, as contrasted to those involving cooperatives, the landlord would merely be using existing facilities to serve persons who otherwise would be customers of the utility. The main purpose of the submetering practice, therefore, appears to be to obtain a monetary benefit resulting from the method by which the rate schedule has been fixed.

Still another type of service is at times demanded by a utility which is engaged in actual competition. A sudden need for service may arise because of a breakdown in the facilities of a company. The duty of a utility to furnish this breakdown service to a rival has been denied in two cases. ${ }^{84}$ In a

77. Wisconsin M. \& P. R. R. v. Jacobson, I79 U. S. 287 (I900).

78. $I d$. at 300 .

79. Id. at 298.

80. Interstate Commerce Comm. v. Delaware I. \& W. R. R., 220 U. S. 235 (I9II).

8I. Sixty-seven South Munn, Inc. v. Board of Pub. Util. Comm'rs, I06 N. J. 45, I47 Atl. 735 (I929), aff'd, I07 N. J. 386, I52 Atl. 920 (I930), cert. denied, 283 U. S. 828 (I931).

82. Lewis v. Potomac Elec. Power Co., 64 F. (2d) 7or (App. D. C. I933).

83. Florida Power \& Light Co. v. State, I07 Fla. 317, I44 So. 657 (I932).

84. Rogers Iron Works v. Public Serv. Comm., 323 Mo. I22, I8 S. W. (2d) 420 (I929); People ex rel. N. Y. Edison Co. v. Public Serv. Comm., IgI App. Div. 237, I81 N. Y. Supp. 259 (Ist Dep't, 1920). 
recent New York Commission case, ${ }^{85}$ however, it was pointed out that the duty exists but that extreme care was to be exercised to make sure that there would be full compensation.

In the final analysis, it would seem that commissions and courts should not concern themselves with the petty rivalry of utilities. ${ }^{86}$ On the other hand, aid should not be extended solely because it will enable a rival to conduct his business. ${ }^{87}$ The true test should lie in the public interest. Thus in a case where competition in fact will exist, the determination of whether the public interest will be benefited by requiring the furnishing of service should be the important question. Such a determination by a commission will involve many facts, and in the absence of arbitrary action it should be conclusive upon the courts. ${ }^{88}$

\section{Discrimination by Utilities Against Cooperatives}

Attempts will probably be made to avoid the furnishing of service to cooperatives on the ground that they are not public utilities within the meaning of commission jurisdiction. Such an argument has been made as to municipalities and has met with judicial approval by way of dictum in an opinion by the majority of the Supreme Court of Illinois in Chicago Dist. Pipe Line Co. v. Illinois Commerce Comm. ${ }^{89}$ A petition for a certificate of convenience and necessity had been filed to obtain the right to sell wholesale to public utility companies. A village intervened on the ground that the order of the commission should direct that service be rendered the village in the event that it constructed a distribution system. The court held that the village had such a remote and contingent interest that it was not a proper party to the proceedings. The majority of the court, however, said that it would not be an unlawful discrimination for the company to refuse service to municipalities, since the legislature itself discriminated with regard to public bodies by providing that they were not public utilities within the meaning of commission legislation. A vigorous dissent attacked the statement of the majority on the ground that a utility has no right to choose its patrons. I937)

85. See In re N. Y. Edison Co., I6 P. U. R. (N. s.) I20, I25 (N. Y. Pub. Serv. Dep't,

86. Cf. People ex rel. Western Union Telegraph Co. v. Public Serv. Comm., 230 N. Y. 95, 129 N. E. 220 (1920).

87. Evansville \& H. Tr. Co. v. Henderson Bridge Co., r34 Fed. 973 (C. C. W. D. Ky. I904); see Wyman, Business Policies Inconsistent with Public Employment (I907) 20 HARv. L. REV. $511,524$.

88. "It is now clearly perceived that what is most needed in the field of business intercourse is expert administrative adjustment, and not court adjudication." Clay County Coop. Telephone Ass'n v. Southwestern Bell Telephone Co., I07 Kan. 169, 174, 190 Pac. 747, 749 (1920).

89. 36r Ill. 296, 197 N. E. 873 (1935). Contra: Fulton v. Panhandle Eastern Pipe Line Co., P. U. R. I933A 256 (Mo. Pub. Serv. Comm. 1932), rev'd on other grounds sub nom. State ex rel. Panhandle Eastern Pipe Line Co. v. Public Serv. Comm., 93 S. W. (2d) 675 (Mo. I936). 
Questions of classification do not lend themselves to general analysis, since "classification good for one purpose may be bad for another." ${ }_{90}$ The reason underlying a classification must be examined in order to determine its justification. The reason for the separate classification of municipalities or cooperatives from public utility companies is that the same cause for administrative control does not exist. The courts, accordingly, have had no diffculty in upholding the classification for that purpose. ${ }^{91}$ The same reason for the separate classification does not exist, however, so far as is concerned the attempt of a utility to discriminate between public utility companies and municipalities and cooperatives. The only apparent reason for an attempt by a utility to make such a classification is to show preference for private enterprise as contrasted to public or democratic ownership and control.

The argument has been made before the Supreme Court of the United States that the ability of a patron to discriminate because of the absence of commission control was a justification for the denial of service to that patron. ${ }^{92}$ In this case, which has already been referred to as involving carload service to forwarding agents who make up the carloads from small shipments by their patrons, the Court held that the contention was foreclosed by the contrary finding of the Interstate Commerce Commission. The same contention could not be made successfully as to cooperatives, since as a practical matter one of their primary tenets is equality. ${ }^{93} \mathrm{~A}$ fortiori it could not be made as to municipalities, which as a matter of law cannot discriminate even if they are not public utilities within the meaning of commission regulation. $^{94}$

An interesting comparison can be made between the Chicago Dist. Pipe Line Co. case ${ }^{95}$ and a North Carolina case. ${ }^{96}$ The former involved wholesale service to public utilities but not to other enterprises, while the latter involved wholesale service to other enterprises, but not to public utilities. In the North Carolina case the court went so far as to consider a company as not being engaged in furnishing wholesale service when it sold to municipalities and to industrial patrons for consumption by employees. The implication of the latter case might be that a duty exists to serve enterprises such as municipali-

go. Louisville Gas \& Elec. Co. v. Coleman, 277 U. S. 32, 38 (1928).

9r. Springfield Gas \& Elec. Co. v. Springfield, 257 U. S. 66 (I92I) ; Yamhill Elec. Co. v. McMinnville, I30 Ore. 309, 274 Pac. II8 (I927), rehearing denied, I30 Ore. 338, 280 Pac. 504 (I929), appeal dismissed, 280 U. S. 531 (1930).

92. Interstate Commerce Comm. v. Delaware L. \& W. R. R., 220 U. S. 235 (I9II).

93. "Their aim is economic democracy on lines of liberty, equality and fraternity." Brandeis, J., dissenting in Frost v. Corporation Comm. of Okla., 278 U. S. 515, 536 (1929).

94. Western Reserve Steel Co. v. Cuyahoga Heights, Ir8 Ohio St. 544, I6I N. E. 920 (I928); Raigle v. Smith, 287 Pa. 30, I34 Atl. 380 (I926). (I935).

95. Chicago Dist. Pipe Line Co. v. Illinois Commerce Comm., 36I Ill. 296, 197 N. E. 873 (I929).

96. Holmes Elec. Co. v. Carolina Power \& Light Co., 197 N. C. 766 , I50 S. E. 62x 
ties and cooperatives irrespective of whether there has been a general holding out to furnish wholesale service.

Certain telephone cases which speak of the right of public utilities to obtain a physical connection should be mentioned. Loose thinking has resulted in an analogy to such cases in deciding other cases where the facts differ in material respects. ${ }^{97}$ It has already been shown that in the absence of statute a telephone company may refrain from furnishing a switchboard connection to another company. ${ }^{98}$ Statutes have been passed, however, which impose this duty, but they expressly provide that the duty exists only for the benefit of public utilities. ${ }^{99}$ Manifestly, if a telephone company is not a public utility, it cannot obtain the benefit of such a statutory provision. ${ }^{100}$ Holdings of this character, therefore, are inappropriate and inapplicable in determining whether the connection for wholesale electric service, which does not differ from a connection for ordinary service, must be made for an enterprise which is not a public utility.

Cooperatives may have different aims from public utility companies. Their theory of operation and especially their policy of non-profit operation by means of patronage refunds may not be consistent with ordinary utility practices, ${ }^{101}$ but this is no ground for discrimination against them. ${ }^{102}$ Contentions that cooperative responsibility is inadequate can be met by appropriate requirements for security. ${ }^{103}$ Inadequacy of cooperative facilities has been suggested as a ground for the denial of service. Even if the factual basis for such a contention were to exist, it would not subject the utility company to liability. ${ }^{104}$ Furthermore, by appropriate and customary circuit breakers such a situation would not impair the general service rendered by the utility to the public. In any event, it is clear that such circumstances could be adequately covered by appropriate rules and regulations as in the case of similar particular characteristics of any other patrons. ${ }^{105}$

97. The confusion is referred to in Fulton v. Panhandle Eastern Pipe Line Co., P. U. R. I933A 256, 266 (Mo. Pub. Serv. Comm. I932).

98. Home Telephone Co. v. Sarcoxie Light \& Telephone Co., 236 Mo. I44, I39 S. W. IoS (IVII).

99. See, e. g., ME. Rev. Stat. (I930) c. 62, § 45.

100. Gilman v. Somerset Farmers Coop. Telephone Co., I29 Me. 243, I5I Atl. 440 (I930) ; cf. Pioneer Tel. \& Tel. Co. v. Grant County Rural Telephone Co., Irg Pac. 968 (Okla. Igrr).

IOI. In Corporation Comm. v. Lowe, 28I U. S. 43 I (I930), the constitutionality of the power of utility cooperatives to give patronage refunds was unsuccessfully attacked.

102. $C f$. the attempt to discriminate by a boycott against a cooperative marketing agency in United States v. American Livestock Comm. Co., 279 U. S. 435 (1929).

103. Wisconsin Rural Electrif. Coordination Comm. v. Lake Superior Dist. Power Co., I6 P. U. R. (N. S.) 238 (Wis. Pub. Serv. Comm. I936).

I04. Cf. Burch v. Southern Bell Tel. \& Tel. Co., I73 So. 300, 30I (Miss. I937), where the court said: "Since, then, the telephone company did not erect this particular line and had no authority or control over the wire in question, it could have no liability in respect to its physical condition or situation."

I05. Wisconsin Rural Electrif. Coordination Committee v. Lake Superior Dist. Power Co., I6 P. U. R. (N. S.) 238 (Wis. Pub. Serv. Comm. I936). 


\section{Conclusion}

The development of the cooperative movement, particularly in rural electrification, will call for the determination of many issues in fields where legal concepts are manifold. Concepts are used or abused depending upon their application. It behooves the legal profession to utilize those concepts as tools to work out the law and not as principles which fix the law. Behind every concept lurks a factual situation not to be ignored. Particular care must be exercised in the application of concepts to social and economic developments in order to avoid any unjust criticisms of a legal lag.

The duties of utilities vary with their character and the nature of the service which they furnish. The making of physical connections between utilities differs factually depending upon the type of utility and the kind of connection. To deduce from cases involving two telephone companies that a physical connection cannot be demanded by an electric cooperative overlooks entirely an essential difference between the two situations. The connection to furnish service to another telephone company differs fundamentally from the service which is furnished the ordinary patron. But the connection between two electric companies or between an electric company and a cooperative differs in no material respect from the service furnished to the ordinary patron.

A number of courts have indicated without discussion that a physical connection, whether between telephone or electric companies, need not be made unless the company has held itself out as furnishing service to other companies. It is conjectural whether courts will follow the language in such decisions or will recognize the fundamental distinction between the two situations and take the position that there is a duty to furnish electricity to another company, even though the utility has never had the occasion to profess to serve other companies.

Attempts to limit utility service solely to the consuming public have been unsuccessful. As pointed out by the Supreme Court of the United States, ${ }^{106}$ a utility cannot sit in judgment on the relationship between its patron and the customers of its patron. Likewise, the territory in which the patron of the utility conducts its business is of no concern to the utility so long as the patron may lawfully serve that territory. Thus the furnishing of electricity concludes the sale by the utility, and the subsequent distribution by a cooperative in another locality does not mean that the utility is engaged in serving that other locality.

The demand of service from a utility in order to compete with it by taking away some of its customers can only be justified if a public interest is present. The determination of the existence of a sufficient public interest in (1920).

I06. Interstate Commerce Comm. v. Delaware L. \& W. R. R., 220 U. S. 235, 252-253 
such cases should be left to adjudication by the public service commissions. Any denial of service on the ground of competition must, as the Supreme Court of the United States has said, ${ }^{107}$ involve competition in fact and not in fancy. Furthermore, the anticipated growth of a utility or of its potential business should not stand in the way of an enterprise which is ready to make the possibility of service an actuality.

The cooperative movement has withstood discriminatory attacks. It will probably be successful in meeting attempts of utilities to discriminate against cooperatives on the ground that they are not subject to commission jurisdiction. As the ramifications of the general problem are reviewed, the impression is clear that the law need not be an obstacle to this phase of the cooperative movement. The pertinent authorities and principles, when analyzed, indicate that the law in the public utility field stands ready to be utilized to assist rather than to block the cooperative movement.

I07. See Wisconsin M. \& P. R. R. v. Jacobson, I79 U. S. 287 (I900). 